\title{
Regional distribution patterns of minerals and chemical components in surface media reflecting and characterising occurrences of kimberlite, ultramafic lamprophyre and carbonatite in West Greenland
}

\author{
Agnete Steenfelt ${ }^{1}$, Sven M. Jensen ${ }^{2}$, Troels F.D. Nielsen ${ }^{1}$ \& Karina K. Sand ${ }^{1,3}$ \\ ${ }^{1}$ Geological Survey of Denmark and Greenland, Øster Voldgade 10, DK-1350 Copenhagen K, Denmark \\ ${ }^{2}$ Intex Resources ASA, Munkedamsveien 45A, N-0250 Oslo, Norway \\ ${ }^{3}$ Nano-Science Center, University of Copenhagen, Universitetsparken 5, DK-2100 Copenhagen Ø
}

(ast@geus.dk)

\begin{abstract}
Southern West Greenland
Chemical data based on stream sediment (Steenfelt, 2001) and kimberlite indicator minerals (KIM) from till (Jensen et al., 2004) have been acquired over a large part of Precambrian West Greenland during diamond exploration and geochemical mapping by commercial companies and the Geological Survey of Denmark and Greenland (GEUS). The data have been compiled, quality controlled and archived and have been used to study the distribution patterns of chemical parameters that are related to the occurrences of kimberlites, ultramafic lamprophyres (UML), lamproites and carbonatites.
\end{abstract}

Nine dyke swarms of lamprophyres and six carbonatite occurrences are known in West and South Greenland. The main emplacement regions are in southern West Greenland as shown in Fig. 1. Emplacement of the alkaline rocks and carbonatites occurred in episodes related to continental rifting and ranging in age from Archaean to Palaeogene (Larsen \& Rex, 1992). Carbonatites occur in central complexes, while lamprophyres, ultramafic lamprophyres and kimberlites are found as dykes and sills. Diamonds have been recovered from both kimberlite and UML, see Fig.1.

Intensive exploration from the 1990s until now has increased the number of occurrences considerably, particularly in poorly known inland areas. A small new Jurassic province (Tikiusaaq, Fig.1) comprising a carbonatite complex and several UML dykes was located as late as 2005 (Steenfelt et al., 2006), and many new dykes have been located in the Maniitsoq region.

Stream sediment and till data displayed on a regional scale reveal that elevated $\mathrm{Nb}$ in stream sediment outline the major regions hosting alkaline dykes and carbonatites, and so does the abundance and distribution of peridotitic garnet (G10 and G10D,
Grütter et al., 2004) recovered from samples of till and glaciofluvial deposits (Fig. 1). Additionally, carbonatites are clearly indicated in stream sediment data by elevated Th, P and LREE.

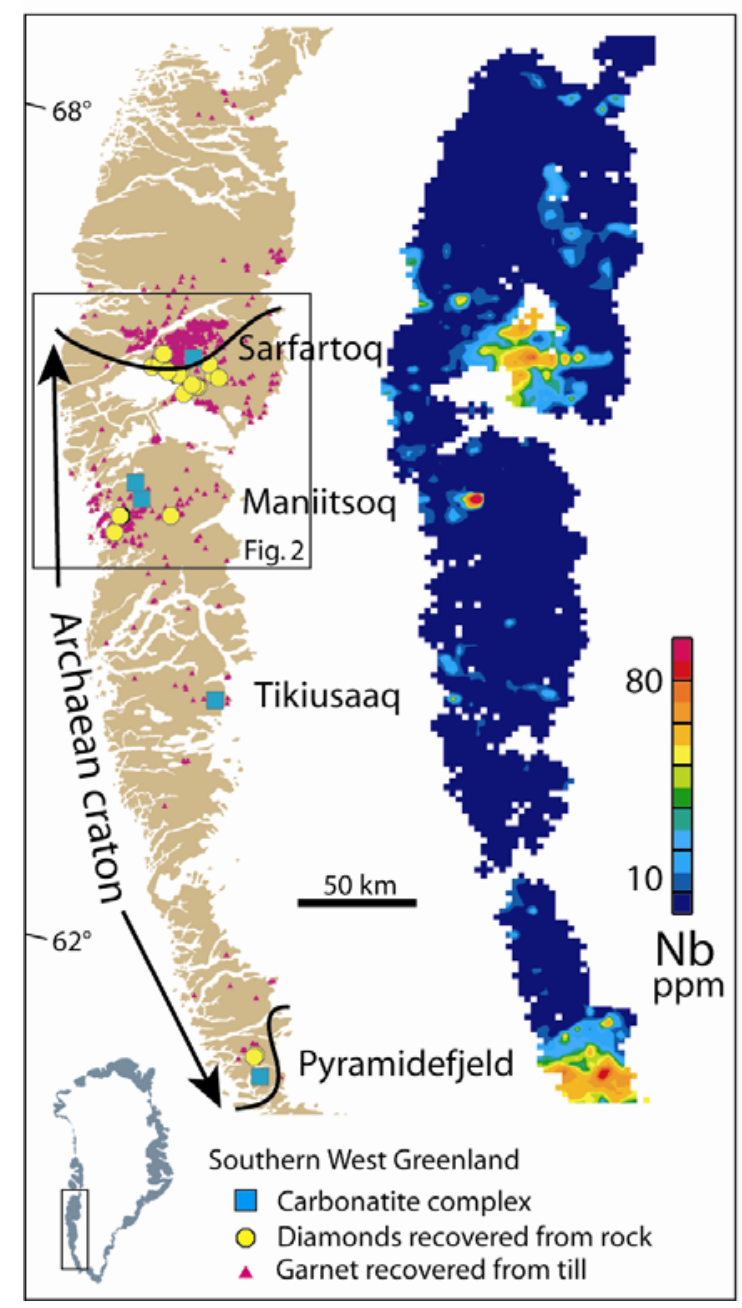

Fig. 1. Main UML/kimberlite/carbonatite provinces in Southern West Greenland, reflected by garnet in till and $\mathrm{Nb}$ in stream sediment (contoured grid). 


\section{Neoproterozoic province}

Special attention has been devoted to the northern part of the Archaean craton, where Neoproterozoic UML and kimberlite dykes are abundant. Two spatially distinct provinces of dykes, Sarfartoq and Maniitsoq, have been recognised at an early stage, although the dykes turned out roughly coeval (Secher et al., this volume), and were for a long time considered similar in character (see Nielsen et al., this volume). Diamond bearing dykes are now known from both provinces.

The Sarfartoq region straddles the craton's northern boundary towards the Palaeoproterozoic Nagssugtoqidian mobile belt, while the southern Maniitsoq region lies entirely within the craton. The topography varies from hilly to mountainous and the bedrock is variably covered by glacial till and glaciofluvial deposits.

The surface data show a much larger $\mathrm{Nb}$ anomaly in stream sediment data, and larger distribution of KIM in till in the Sarfartoq region as compared with the Maniitsoq region. With Canadian conditions in mind and known ice movement towards the west, the shape of the KIM distribution at Sarfartoq might suggest a major kimberlite occurrence in the poorly exposed area to the east of the KIM cluster. To examine this possibility, studies of the dispersion of KIM around known dykes, as well as the mineral assemblages and chemistry within these dykes, were undertaken by GEUS in collaboration with the Bureau of Minerals and Petroleum, government of Greenland (Jensen et al., 2005, Steenfelt et al., 2005).

The studies concluded that the glacial transport is short in mountainous Greenland (unlike in flat Canada), so that glacially far-transported material does not contribute to any significant degree to the distribution patterns. The regional difference in KIM and Nb quantity was found to be caused by different setting of the dykes. The UML in the Sarfartoq region have been emplaced in gneisses with shallow-dipping structural grain, hence mainly as abundant thin sills; although a few more massive and steep dykes also occur. Glacial reworking and weathering have resulted in a littering of UML boulders that have sourced the abundance of $\mathrm{KIM}$ and $\mathrm{Nb}$ recovered from (relatively thin) overburden. In the Maniitsoq region, the dykes have been emplaced in steeply dipping gneisses, as steep massive and consistent dykes, in a more elevated, glacially abraded terrain, where the dispersion of KIM from the dykes is limited and largely due to postglacial downhill movement of weathering material.

The distribution patterns of boulders, diamond localities, and KIM data are shown in Fig. 2.

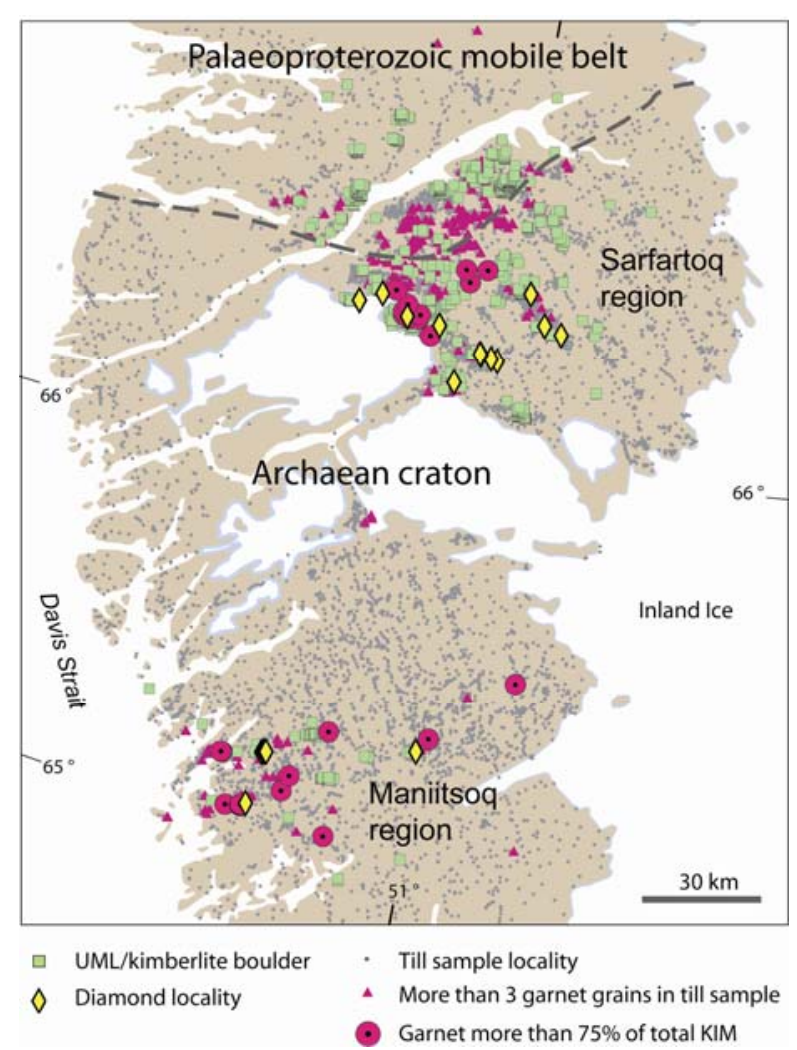

Fig. 2. Neoproterozoic UML/kimberlite province in southern West Greenland. KIM results from abundant samples of till (glacial overburden s.l.) show that KIM amount is high, where boulders are abundant. High relative amount of peridotitic garnet shows spatial correlation with diamondiferous rocks.

Interestingly, localities with a high garnet proportion only occur south of the northern craton margin, as do the diamond bearing rocks identified so far. Tests for diamonds from rock samples north of the craton gave negative results.

Differences in KIM quality between the two regions were found to reflect differences in the KIM of the rocks themselves. This is exemplified by $\mathrm{MgO}$ concentrations in ilmenite (Fig. 3), where MgO display higher values in the Maniitsoq region (latitude 65-66 $\mathrm{N}$ ) than in the Sarfartoq region (66 to $67 \mathrm{~N}$ ). 


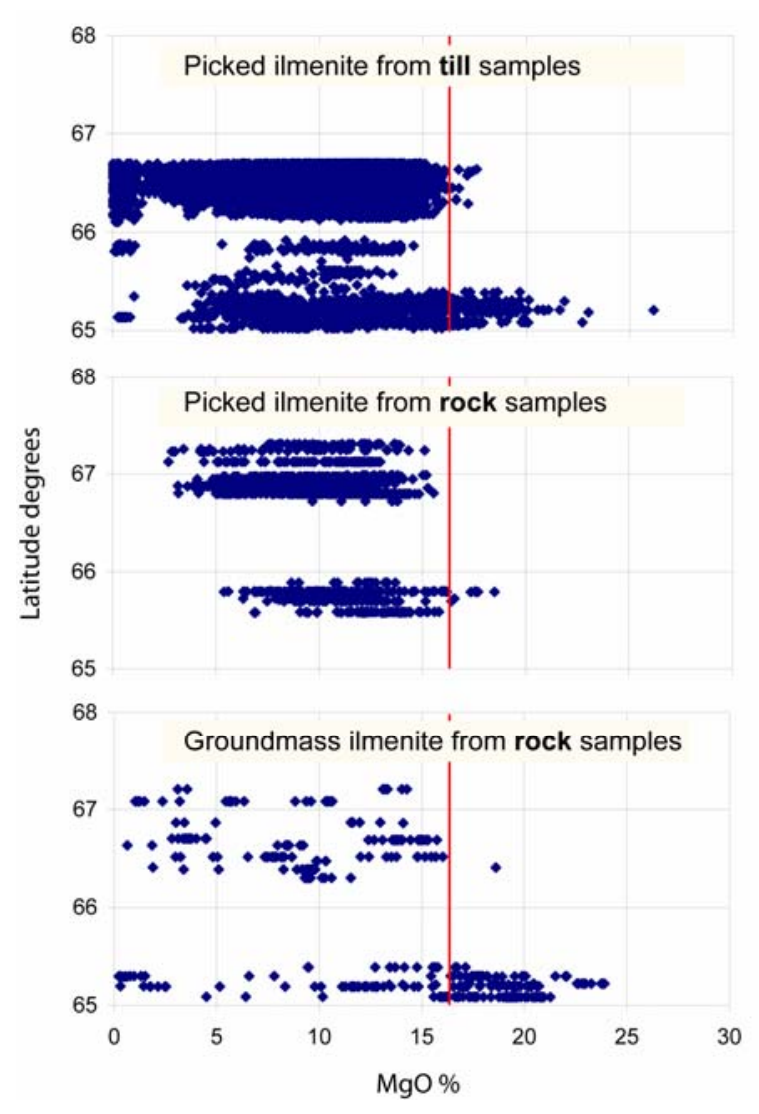

Fig. 3. Microprobe analyses of ilmenite grains from different media show a large variation in $\mathrm{MgO}$ with higher values occurring consistently in the Maniitsoq region (south of $66^{\circ}$ northern latitude). The ilmenite data of till samples reflect properties of rock samples. Red line marks upper limit of $\mathrm{MgO}$ in groundmass ilmenite from UML in Sarfartoq.

Recent studies of magma compositions have substantiated the differences in magma compositions and indicated that the Sarfartoq dykes are largely UML, whereas the Maniitsoq region comprises mainly carbonatite-rich kimberlites (Nielsen et al. 2006; Nielsen et al., this volume). The difference is ascribed to the position of the areas in relation to the craton margin.

Xenolithic mantle material, on the other hand, has been shown to be derived from the diamond stability field in both regions (Sand et al., this volume). This, together with the actual diamond finds sustains the diamond potential in large parts of the Neoproterozoic UML/kimberlite province.

The results of the studies of KIM distribution and composition are important for the use of indicator minerals to track potentially diamond bearing dykes in poorly exposed or poorly known areas of West Greenland, and they have contributed to an increasing interest in the diamond potential of the Maniitsoq region.

\section{References}

Grütter, H.S., Gurney, J.J., Menzies, A.H. \& Winter, F. 2004: An updated classification scheme for mantle-derived garnet, for use by diamond explorers. In: Mitchell, R.H. et al. (eds): Selected Papers from the Eighth International Kimberlite Conference. Volume 2: The J. Barry Hawthorne Volume. Lithos 77, 841-857.

Jensen, S.M., Secher, K., Rasmussen, T.M., \& Schjøth, F. 2004: Diamond exploration data from West Greenland: 2004 update and revision. Geological Survey of Denmark and Greenland Report 2004/117, 90 pp and 1 DVD.

Jensen, S.M., Sand, K.K. \& Steenfelt, A. 2005: Regional distribution and chemistry of indicator minerals from in situ rocks and surficial deposits in the Maniitsoq and Sarfartoq regions. Geological Survey of Denmark and Greenland Report 2005/68, 43-51.

Larsen, L.M. \& Rex, D.C. 1992: A review of the 2500 Ma span of alkaline-ultramafic, potassic and carbonatitic magmatism in West Greenland. Lithos 28, 367-402.

Nielsen, T.F.D. \& Jensen, S.M. 2005: The Majuagaa calcitekimberlite dike, Maniitsoq, southern West Greenland. Geological Survey of Denmark and Greenland Report 2005/43, 59 pp.

Nielsen, T.F.D., Jebens, M., Jensen, S.M. \& Secher, K., 2006. Archetypal kimberlite from the Maniitsoq region, southern West Greenland and analogy to South Africa. Geological Survey of Denmark and Greenland Bulletin 10, 45-48.

Nielsen, T.F.D., Jensen, S.M., Secher, K. \& Sand, K.K., this volume: Regional and Temporal Variations in the Magmatism of the Diamond Province of southern West Greenland. Extended Abstract 9IKC-A-00221.

Sand,K.K., Waight,T., Nielsen, T.F.D., Pearson, D.G., Makovicky, E. \& Hutchison, M., this volume: Fourphase geo-thermobarometry on mantle xenoliths from West Greenland: assessment of P/T-formulations and implications for diamond potential. 9IKC Extended Abstract 9IKC-A-00146.

Secher, K., Nielsen, T.F.D., Heaman, L.M., Jensen, M.S. \& Schjøth, F., this volume: Emplacement patterns of kimberlites and ultramafic lamprophyres in an alkaline province located $64-67^{\circ} \mathrm{N}$ in southern West Greenland - Evidence from 40 new, robust age analyses. Extended Abstract 9IKC-A-00173.

Steenfelt, A. 2001: Geochemical atlas of Greenland - West and South Greenland. Geological Survey of Denmark and Greenland Report 2001/46, 39 pp. + 1 CD-ROM.

Steenfelt, A., Jensen, S.M. \& Sand, K.K. 2005: Distribution of kimberlite indicator minerals in till within the Neoproterozoic Sarfartoq-Maniitsoq province of kimberlite and ultramafic lamprophyres, southern West Greenland. Geological Survey of Denmark and Greenland Report 2005/68, 109-113.

Steenfelt, A., Hollis, J.A. \& Secher, K. 2006: The Tikiusaaq carbonatite: a new Mesozoic intrusive complex in southern West Greenland. Geological Survey of Denmark and Greenland Bulletin 10, 41-44. 